\title{
Beef Supply Chain Analysis to Improve Availability and Supply Chain Value Using System Dynamics Methodology
}

\author{
Purnama Anaking and Erma Suryani \\ Department of Information System, Institut Teknologi Sepuluh Nopember, Surabaya \\ e-mail: erma.suryani@gmail.com
}

\begin{abstract}
Abstrak-The research focuses on beef commodity where beef demands data continue increasing proportionate or in line with increasing population, national per capita income, and the needs of industrial foods process materials. On the other hand, domestic beef supply tends to decrease so it can't meet domestic demand. Furthermore, there are problems with fulfilling supplies to the end customer. The effort in solving the problems by improving the supply chain process using a model-driven decision support system, to model the existing system and build new scenarios to increase beef supply chain performance. The model-driven decision support system approaches using a system dynamics model to accommodate key variables or parameters that significantly contribute to the continuity strategic beef supply chain. The results showed a policy scenario with success indicators in the form of optimizing average beef weight values to $300 \mathrm{kgs}$ per cattle and with carcass percentage value at $55 \%$ life weight, projecting deficit beef values decreasing in each year. At 2027 deficit value becoming small which is 8,520 tons, which ends up becoming surplus in 2028. The results of the model-driven decision support system output scenario can be functioned as input to the decision-maker to elaborate policy process related to the beef's food sector to achieve food self-sufficiency which one of the government missions.
\end{abstract}

Kata Kunci-Model, System Dynamics, Beef Availability, Supply Chain, Policy Scenario.

\section{INTRODUCTION}

$\mathrm{T}$ HE Directorate of Food and Agriculture in 2013 said that beef production was still unable to meet domestic needs so that the level of dependence on imports was still very high. Beef in 2012 experienced a production deficit of 78,329 tons or $21.46 \%$ [2]. Meanwhile, beef consumption or demand will continue to increase directly proportional to population growth, real income per capita, product image (prestige), taste, and growth of the beef processing industry and the tourism industry (hotel and restaurant).

This is also in line with what is said by BAPPENAS in 2013 regarding the development of total domestic consumption of beef during 2008-2012 [2]. The total consumption of beef during this period continues to increase quite rapidly with an average of $8.11 \%$ per year. In 2012, total beef consumption reached around 544.9 thousand tons, far greater than the total consumption in 2008 which was only around 395.2 thousand tons [2]. And from this data it was also seen that there was a beef deficit in 2008-2012.

The foregoing also influences the export behavior of Indonesian beef commodity imports. Indonesia imports cattle in the form of beef and livestock to be fattened. The majority of the origin of beef is New Zealand and Australia, while the origin of feeder cattle is only Australia. Beef exports from Indonesia are very small and negligible, and beef exports do not even exist [2].

Demand for beef in Indonesia also continues to increase, along with an increase in people's income and changes in tastes toward quality meat. In the next three years, the level of meat consumption is expected to increase from $1.6 \mathrm{~kg}$ to $2.3 \mathrm{~kg} /$ capita / year. This is synonymous with slaughtering cattle by 2.2 million head (30\%), so that it takes an additional around 300 thousand head of cattle each year. If these needs are not able to be provided from people's farms, meat imports are expected to increase. In the period 2000-2012 there was a higher population growth compared to the previous period. The trend of beef cattle population development shows a more positive increasing trend. This is shown in the 20052012 period, the average population growth of cattle reaches $6.02 \%$ per year, and the total population and national beef production are 16.03 million heads and 505.5 thousand tons, respectively. The policy of self-sufficiency needs to be carried out intensively by the government through related agencies to increase beef production, and in the end it will reduce national beef imports [2].

As stated above, that one of the variables influencing an increase in beef consumption is a population growth that continues to increase. The population of Indonesia over the next twenty-five years continues to increase, from 238.5 million in 2010 to 305.6 million in 2035 [1].

The average growth per year of the Indonesian population during the period 2010-2035 shows a downward trend. In the period 2010-2015 and 2030-2035 the population growth rate dropped from 1.38 percent to 0.62 percent per year [1].

This decrease in growth rate is determined by the decline in birth and death rates. The rate of decline due to birth is faster than the rate of decline due to death. Crude Birth Rate (CBR) fell from about 21.0 per 1000 population at the start of the projection to 14.0 per 1000 population at the end of the projection period, while the Crude Dead Rate (CDR) rose from 6.4 per 1000 population to 8.8 per 1000 population in the same period [2].

Nevertheless, this increasing population continues to be followed by an increase in Indonesia's per capita income, so this will visibly affect the increasing demand for beef in the future. The Central Statistics Agency (BPS) announced the nominal per capita income of Indonesia in 2013 reached Rp. 36.5 million. Up by Rp. 3 million compared to the previous year's per capita income of 33.5 million. According to the 


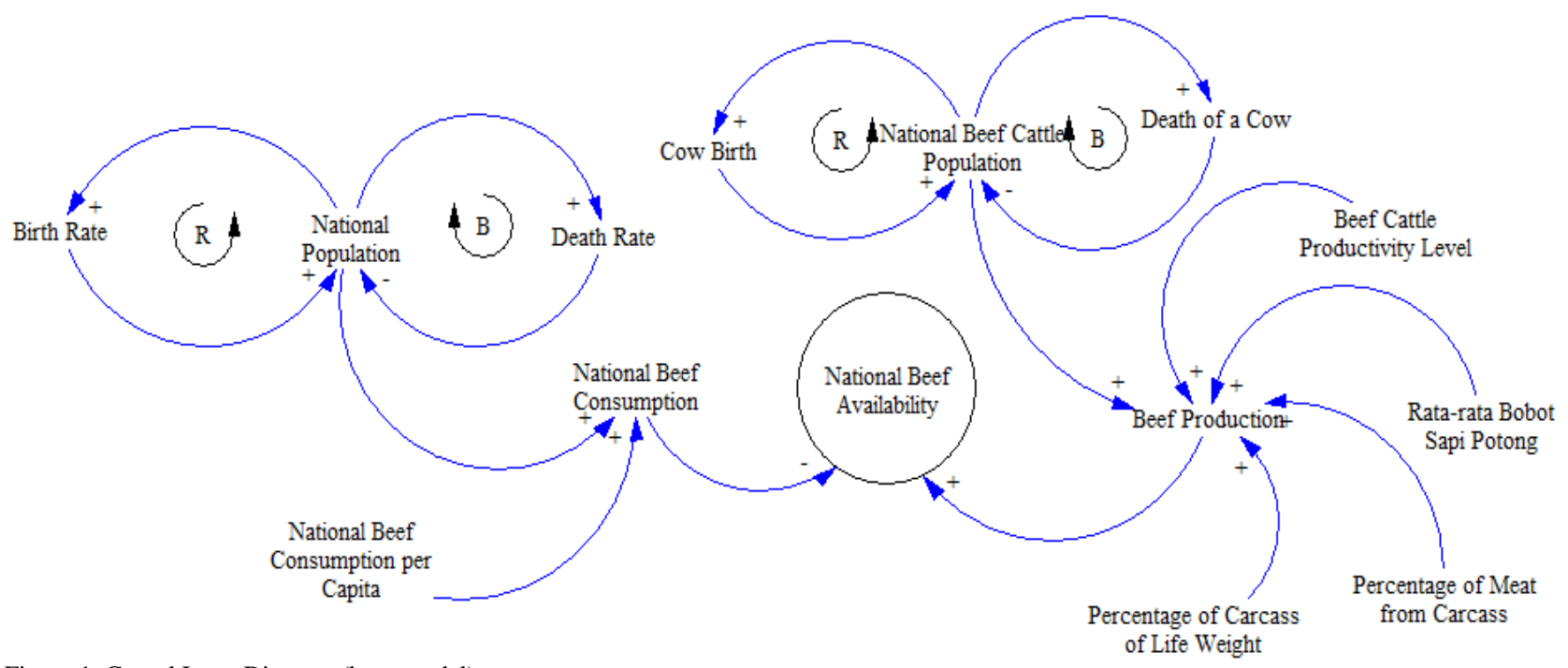

Figure 1. Causal Loop Diagram (base model).



Figure 2. Stock Flow Diagram.

Head of BPS Suryamin, this is a positive trend because for three consecutive years our per capita Gross Domestic Product has increased [13].

According to the Indonesian Institute of Sciences (LIPI) national beef consumption is predicted to continue to increase in the next few years. In 2030 Indonesia must prepare 12.3 million tons of meat for 286 million people with the assumption of an increase in consumption of $43 \mathrm{~kg} /$ capita. The head of LIPI said that in 2030, GDP is expected to be USD 7,600 and meat consumption to be $45 \mathrm{~kg}$ / capita in the world average. While 2025 is predicted that Indonesia's population will reach 271.3 million with a growth of $1 \%$ per year [6].

The above description is related to the problem of Indonesia's food security. In Law Number 18 of 2012 concerning food it is stated that food is the most basic human need and its fulfillment is part of human rights guaranteed in the 1945 Constitution of the Republic of Indonesia as a basic component to realize human resources that are quality [12]. In its journey food security is an important issue for the Indonesian people and is still one of the priorities in the national development program. This is evidenced in the 2015-
2019 National Medium Term Development Plan (RPJMN) which places the issue of increasing food sovereignty into one of the sub parts of the national development agenda, namely realizing economic independence by moving strategic sectors of the domestic economy.

Food sovereignty is reflected in the power to regulate food problems independently, which needs to be supported by: (i) food security, especially the ability to provide food from domestic production; (ii) food policy arrangements that are formulated and determined by the nation itself; and (iii) able to protect and prosper the main actors in food [12]. Some strategic targets for the 2010-2014 RPJMN have not yet been reached, namely strategic food self-sufficiency such as beef. Beef production is still far from the target. At present the Indonesian government is determined to achieve selfsufficiency in future food supplies. Among the government's food sovereignty targets in the 2015-2019 RPJMN is the achievement of increased availability of beef food sourced from domestic production to secure beef consumption. The target of 2015-2019 food sovereignty for beef production is 755.1 thousand tons from the 2014 baseline of 452.7 thousand tons with an average 2015-2019 growth of $10.8 \%$ [12]. 
The $6^{\text {th }}$ International Seminar on Science and Technology (ISST) 2020

July $25^{\text {th }} 2020$, Institut Teknologi Sepuluh Nopember, Surabaya, Indonesia

Table 1.

National Meat Projection Availability Based on Scenario

\begin{tabular}{lllr}
\hline \hline Year & \multicolumn{1}{c}{ Consumption (ton) } & Production (ton) & Deficit \\
\hline $\mathbf{2 0 1 9}$ & $794,225.50$ & $695,639.88$ & $98,585.63$ \\
$\mathbf{2 0 2 0}$ & $830,055.63$ & $738,182.75$ & $91,872.88$ \\
$\mathbf{2 0 2 1}$ & $866,599.56$ & $782,607.81$ & $83,991.75$ \\
$\mathbf{2 0 2 2}$ & $903,868.75$ & $828,988.81$ & $74,879.94$ \\
$\mathbf{2 0 2 3}$ & $941,875.06$ & $877,401.75$ & $64,473.31$ \\
$\mathbf{2 0 2 4}$ & $980,630.44$ & $927,925.44$ & $52,705.00$ \\
$\mathbf{2 0 2 5}$ & $1,020,147.00$ & $980,641.63$ & $39,505.38$ \\
$\mathbf{2 0 2 6}$ & $1,060,437.13$ & $1,035,635.06$ & $24,802.06$ \\
$\mathbf{2 0 2 7}$ & $1,101,513.38$ & $1,092,993.38$ & $8,520.00$ \\
$\mathbf{2 0 2 8}$ & $1,143,388.25$ & $1,152,807.38$ & $(9,419.13)$ \\
\hline \hline
\end{tabular}

$120.000,00$

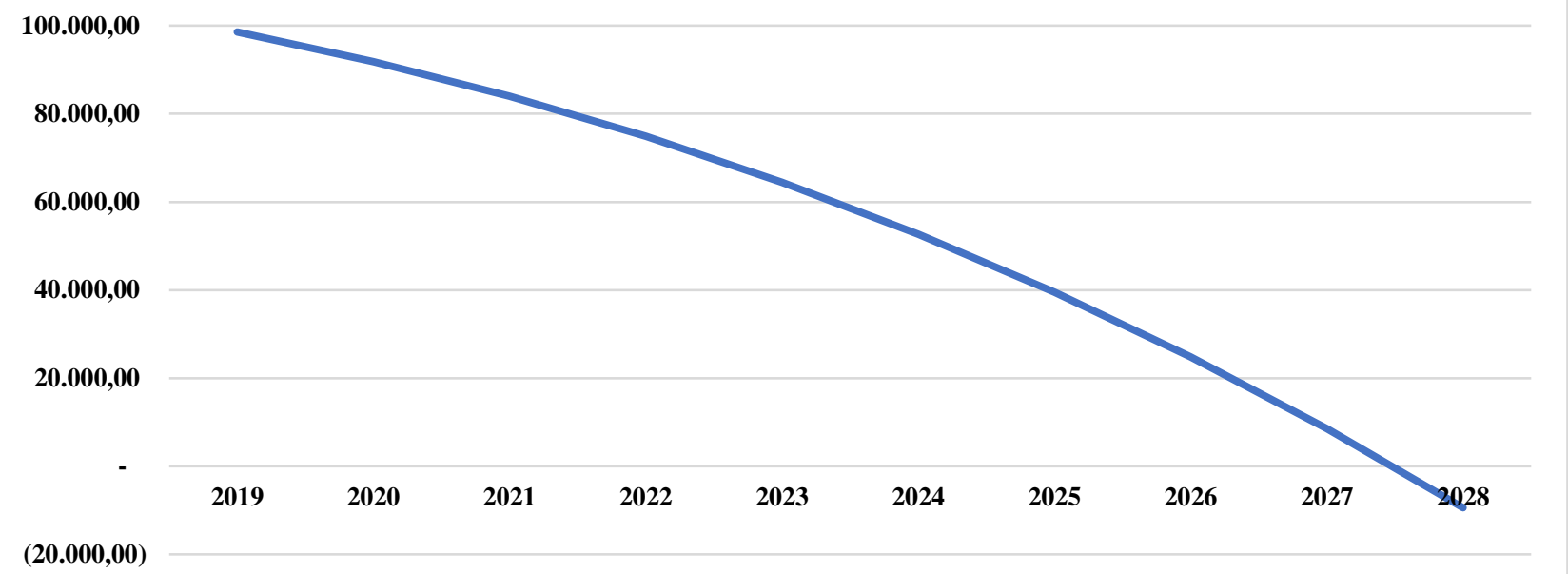

$(20.000,00)$

Figure 3. Graphic Projection of National Beef Based on Scenario.

The research focuses on beef commodities based on the increasing demand for beef, which is directly proportional or in line with increasing population, national per capita income and also the need for processed food industry materials. Whereas on the other hand domestic beef supply tends to decrease so that it cannot meet domestic demand. And also the problem of meeting the supply to the end consumers. A strategic and systematic solution design is needed to anticipate shortages of supply and fulfillment into consumers' hands from beef commodities, where importing these commodities is proven to be unable to solve problems and be counter-productive with the idea of government food selfsufficiency.

This research will discuss key issues to achieve sustainable beef supply through the development of a set of system dynamics model that can accommodate risks and uncertainties in the food supply chain system such as changes and uncertainties in economic conditions.

In other previous research, beef supply chain analysis was examined using survey methods. The issue of beef availability is precisely modeled using system dynamics methodology because it has characteristics, which has a dynamic nature (changes with time) and the structure of the phenomenon contains at least one feedback structure [11].

The reason the Model-Driven Decision Support System approach uses system dynamics model is to accommodate key variables or parameters that have a significant contribution to the sustainable strategic beef supply chain.
System dynamics simulation provides feedback to decision makers about the possibilities that will occur as a result of policy implementation, this is achieved by simulating the system [14].

The system dynamics simulation methodology provides a new approach in looking at supply chain management problems as a whole problem that is influenced by several factors so that it needs a comprehensive solution. The model built will be simulated so as to provide a real picture and replace the trial and error method in determining decision making policies [5]. The model output can also be utilized to develop information technology content to support the competitiveness of national supply chains.

From this, the main issues that arise and will be examined in this research are as follows: a) What variables are significant, in the production system and supply chain of beef that affect the availability of national beef food, b) How to increase meat availability cattle (reducing the beef deficit rate) by analyzing the output of a system dynamics simulation model of the national beef production system. In detail, the objectives of this study are as follows: a) Develop a system dynamics model to analyze the national beef availability system. b) The output of the system dynamics model can serve as input to policy makers in developing policy processes related to the beef food sector in achieving food self-sufficiency which is one of the government's missions.

Contributions that can be made by conducting this research are as follows: a) The creation of a model that helps decision 
The $6^{\text {th }}$ International Seminar on Science and Technology (ISST) 2020

July $25^{\text {th }} 2020$, Institut Teknologi Sepuluh Nopember, Surabaya, Indonesia

makers to achieve a sustainable beef food supply chain. b) System dynamics models will allow to accommodate several key variables or parameters that have a significant contribution to the development of strategic and sustainable supply chains.

\section{METHODS}

This research uses a system dynamics approach with the following stages.

\section{A. Study of Literatur}

In this stage the search for information and literature related to the research conducted. The literature consists of information related to the system under study. Related data needed in research. In addition, literary information regarding the method to be used in analyzing existing data is also needed. The required literature is usually obtained from a similar paper which states the method is suitable for use in the form of data such as the data in the following research.

\section{B. Problem Identification}

In this research, first an analysis of the issues that will be raised. Described based on the main problems and issues related to these problems. This problem identification is done to find out the main problem and predict the things that can be done to overcome the problem.

In this case, a problem was identified regarding the national beef availability system. How does the current system run, is it effective, are there problems that arise, what are the factors that influence this process, and whether the parameters in a system of beef availability are effective and efficient.

\section{Data Collection}

Data are needed regarding the following points, namely the population of Indonesia, beef cattle population in Indonesia, the value of beef consumption in Indonesia, the value of beef production in Indonesia and also the search for data on variable parameter values used or assumed in the study, such as value of population birth rate, population death rate, cow birth rate, mortality rate, consumption level of per capita beef, and others. This data collection is done to look for needs in the research process.

\section{System Dynamics Model}

In a problem that is solved using a simulation, the initial stage of the process is to create a model of the system to be analyzed. The model is used to illustrate how the system will be analyzed in order to create other scenarios that make it possible to make the system more effective and effective.

The model is made with components including the subjects involved in the system, the factors that influence it, and the objects that are subject to work and the effects of the system. By doing modeling it will be easier to further understand the current conditions of the observed system.

The process of making a model in this case is modeling the national beef availability system. Next is the initial model which is represented in the form of a causatic diagram showing the causal relationship between significant variables (see Figure 1).

\section{E. Screening and Result Analysis}

This stage is used to display the results of the analysis conducted and provide conclusions on the results of research conducted and provide useful advice for the development or improvement of further research. The results of the initial modeling will be carried out the process of forming scenarios which will then be analyzed in order to obtain a model that can improve the effectiveness and efficiency of the process of increasing the availability of national beef.

The flow of the development of this scenario is based on the initial model (base model) of the actual system simulation. Then the initial model is verified and validated, then after the model has been verified and valid the scenario development is carried out based on the purpose of making the following research, which is to increase the availability of national beef.

\section{RESULT AND DISCUSSION}

This chapter will explain the development of a cattle supply chain system model based on real phenomena that occur, validation of simulation results from the development of the model, and scenarios offered in developing a policy process related to the beef food sector in achieving food selfsufficiency which is one of the government's missions.

\section{A. Causatic Diagram}

The next stage is to make a causatic diagram to illustrate the system conceptually. This diagram explains the relationship between each variable and the effects that arise from each relationship that occurs. Causatic diagram is created by determining the variables that influence the system.

This diagram illustrates the relationship of positive (+) and negative (-) effects on the system. In the system of beef availability, it is depicted in the form of a causatic diagram with significant variables including the total national beef consumption and the total national beef production (see Figure 1).

In the centered diagram, a sub-model that has a linkage and causal relationship is described, including the national population, the national beef population, and the national beef availability system itself.

Beef availability is positively influenced by total beef production and negatively affected by beef consumption. The total consumption of beef itself is influenced by the level of consumption per capita of society and is also proportional to the population of Indonesia. The population is affected by the birth rate and also the annual death rate.

The total national beef production is influenced by how much beef cattle population can be produced and is also related to other variables such as the average weight of beef, the percentage of carcass from cow weight, percentage of meat from carcass, and also the level of productivity of beef slaughter. Existing beef cattle population is influenced by the rate of birth of cows and also the death rate of existing cows. 
The $6^{\text {th }}$ International Seminar on Science and Technology (ISST) 2020

July $25^{\text {th }} 2020$, Institut Teknologi Sepuluh Nopember, Surabaya, Indonesia

\section{B. Flow Diagram}

The next stage is the making of a formulation model or what is called a flow diagram. Flow diagram are used to describe or simulate the flow of national beef supply systems. To be able to make a flow diagram the following things are done. First, determine the factors of the system which are factors whose value changes from time to time denoted by level. Second, determine the rate of addition and subtraction from the level and the things that affect it, symbolized in the form of Rate. Third, determine auxiliary variables that will be the parameters.

The data flow of a beef availability system was developed based on the analysis of the factors in the causatic diagram and developed according to the variables that are the main variables (see Figure 2).

\section{1) Indonesian Population Sub Model}

This sub-model is a factor that influences the amount of beef consumption. In this sub-model there is a loop that causes the population value to change continuously. According to data from the Central Statistics Agency, Indonesia's population in 2010 amounted to 239.065 million people until 2019, increasing to 268, 482 million people [17].

\section{2) Indonesian Beef Cattle Population Sub Model}

This sub-model is a factor that influences the amount of beef production. In this sub-model there is a loop which causes the value of beef cattle population to change continuously. According to data from the Central Statistics Agency, the population of Indonesian beef cattle in 2010 was 13.581 million and in 2019 it increased to 17.106 million [17].

\section{3) National Beef Availability Sub Model}

This sub-model is influenced by the Indonesian population sub-model and also the Indonesian beef cattle population submodel. And also influenced by other significant variables (see Figure 2). The availability of meat is the difference between beef consumption and beef production. Beef consumption is influenced by the growth of Indonesia's population and also the level of beef consumption per capita. Beef production is influenced by the population of beef cattle, the average weight of beef cattle, the level of productivity of beef slaughtering, the percentage of meat from carcasses, and the percentage of carcasses from live weight.

\section{Model Verification}

Model verification is a step to determine whether the model has been able to run well. This is evidenced by the absence of an error when the model is run by using a tool or supporting application in making modeling and simulation using a system dynamics.

In this modeling, the application used to do the simulation is the Vensim (Ventana Simulation). From the model that was made in the previous stage, running model was carried out in Vensim. The simulation can be run well.

\section{Model Validation}

Model validation is a way to check whether a conceptual simulation model is an accurate representation of the real system being modeled. Model validation is done by comparing the simulation data with the original data obtained from the company. This is done to prove clearly that the simulation data is in accordance with company data so that the model created can be declared valid.

\section{1) Indonesian Population}

This research takes data on Indonesian population in 20102019. From these data then a simulation of the base model that has been developed is then compared between real data with simulation results from the population of Indonesia. In 2010 the population was 239 million and in 2019264 million. Then to validate the data from the simulation results, a comparison of Mean and Error Variance is performed. The value of $\mathrm{E} 1$ is $1 \%$ and the value of $\mathrm{E} 2$ is $13 \%$.

From the results of the validation test, it can be said that for the sub-model the total population of Indonesia is valid, because the value of E1 $<5 \%$ and the value of E2 $<50 \%$.

\section{2) National Beef Cattle Population}

Next is to test the validity of the national beef cattle population sub-model. Real data is taken for 2010-2019. The real data of beef cattle population in 2010 was 13,581 million and in 2019 there were 17,106 million head. Then run a simulation of the base model that has been developed, found that the number of beef cattle population in 2010 was 13.581 million and in 2019 as many as 17.566 million head.

Furthermore, after calculating the Mean and Error Variance, the value of E1 is $1 \%$ and the value of E2 is $7 \%$. From these results it can be said that the national beef cattle sub-system population is valid.

\section{3) National Beef Availability}

National beef availability sub-model is shown by the value of beef deficit from time to time. Where the deficit value is the total value of beef consumption reduced by the total value of national beef production. The real data used is beef consumption and production data for 2010-2019. the deficit value in 2010 was 90,807 tons and in 2019 it was 265,222 tons. Simulations were also carried out over a period of 20102019 based on the base models that had been developed. The simulation results shows where in 2010 the deficit value was 91,641 tons and in 2019 the value of beef deficit was 265,578 tons.

E1 value is $4 \%$ and E2 value is $2 \%$. From the results of this validates test it can be said that the base model that has been developed is valid, with a reference that the value of E1 $<3 \%$ and the value of E2 $<50 \%$.

The projection of national beef availability which is represented by the value of beef deficit from time to time. The simulation is carried out for 2019 until 2028 (see Table 1). The production value in 2019 is 695,639 tons, which gradually increases from year to year. In 2027 the deficit value will be small, namely as much as 8,520 tons, which will eventually reach a surplus value in 2028 , where the value of production is more than the value of beef consumption. From Table 1 it can be seen that in 2028 there will be 9,419 tons of surplus beef (see Figure 3).

\section{CONCLUSION}

Some of the things that become conclusions in the work of 
The $6^{\text {th }}$ International Seminar on Science and Technology (ISST) 2020

July $25^{\text {th }} 2020$, Institut Teknologi Sepuluh Nopember, Surabaya, Indonesia

this research are as follows:(1)In modeling and simulation using system dynamics methods, the stages of model development are passed, including defining the system, identifying problems, making conceptual models, formulating models, validating and simulating models, designing scenarios implementation, and analysis of simulation results; (2)Significant variables used in the study where this variable affects the availability of beef systems are, the population of Indonesia, the population of Indonesian beef cattle, the level of beef consumption per capita, the average weight of beef cattle, the level of productivity of beef slaughtering, the percentage of meat from carcasses, the percentage of carcasses of body weight; (3)The model that has been built has been verified and meets the validity based on the value of E1 (mean) $<5 \%$ and E2 (error variance) < $30 \%$; (4)The scenario to increase the availability of national beef or reduce the value of beef deficits in a sustainable manner is with a policy scenario with indicators of success in increasing or optimizing the average value of beef cattle to $300 \mathrm{~kg}$ per head and with the carcass percentage value of $55 \%$ live weight; (5)Simulations with these scenarios provide projections of the value of beef deficits decreasing annually. In 2027 the deficit value will be small, namely as much as 8,520 tons, eventually reaching a surplus value in 2028 .

Suggestions arising from the work of the following research and can be used to develop topics and problems in subsequent research are:(1)The government provides a minimum target and also a mechanism that supports the minimum weight of beef cattle to support the intake or supply of national beef availability. So that the value of the beef deficit can be sustained continuously for many years to come;(2)More knowledge is needed in the system dynamics model approach to ensure greater accuracy of the model used. In addition to the factors that have been used, factors that might appear in the future can be added.

\section{REFERENCES}

[1] Badan Perencanaan Pembangunan Nasional. "Proyeksi Penduduk
Indonesia 2010-2035”. Badan Pusat Statistik. 2013.

[2] Badan Perencanaan Pembangunan Nasional. "Studi Pendahuluan Rencana Pembangunan Jangka Menengah Nasional (RPJMN) Bidang Pangan dan Pertanian 2015-2019”. Direktorat Pangan dan Pertanian. 2013.

[3] Dewan Ketahanan Pangan. "Kebijakan Umum Ketahanan Pangan 2010-2014”. 2010.

[4] Daniel J. Power, Frada Burstein, and Ramesh Sharda. "Reflections on the Past and Future of Decision Support Systems: Perspective of Eleven Pioneers”. Springer. Decision Support. An Examination of the DSS Discipline. 2011.

[5] Eko Muh Widodo, Yun Arifatul Fatimah, Sigit Indarto. "Simulasi Sistem Dinamik untuk Meningkatkan Kinerja Rantai Pasok (Studi Kasus Industri Kulit PT Lembah Tidar Jaya Magelang)”. JATI Undip, Vol V, No 3, September 2010.

[6] Gatra News. "Konsumsi Daging Sapi pada 2030 Sekitar 12, 3 Juta Ton per Tahun". 2013

[7] Harmini, W.A Ratna, dan A. Juniar. "Model Dinamis Sistem Ketersediaan Daging Sapi Nasional". Jurnal Ekonomi Pembangunan Vol. 12, No. 1, June 2011, pp.128-146.

[8] H. Steinfeld, T. Wassenaar \& S. Jutzi. "Livestock production systems in developing countries: status, drivers, trends". Rev. sci. tech. Off. int. Epiz., 2006, 25 (2), 505-516.

[9] Purba, P.U Hadi. "Beef Cattle Product Marketing Dynamics in Eastern Indonesia". Analisis Kebijakan Pertanian. Vol. 10, No. 4, December 2012, pp. 361-373.

[10] Juniar Atmakusuma, Harmini, Ratna Winandi. "Mungkinkah Swasembada Daging Terwujud?". Risalah Kebijakan Pertanian dan Lingkungan Vol. 1, No. 2, August 2014, pp. 105-109.

[11] John D. Sterman. "System Dynamics: Systems Thinking and Modeling for a Complex World". Massachusetts Institute of Technology. Engineering Systems Division. 2002.

[12] Kementerian Perencanaan Pembangunan Nasional. "Rencana Pembangunan Jangka Menengah Nasional (RPJMN) 2015-2019", Peraturan Presiden Republik Indonesia Nomor 2 Tahun 2015. 2014.

[13] Merdeka. "Pendapatan Rata-Rata Penduduk Indonesia 2013 Rp. 36,5 Juta". 2014.

[14] M. Nurman Helmi. "Simulasi Sistem Dinamis Dalam Manajemen Rantai Pasok". INFOMATEK, Vol. 7, No. 4, December 2005.

[15] Rochadi Tawaf, Hasni Arief. "Strategi Pendekatan Ketersediaan Daging Nasional di Indonesia”. Seminar Nasional: Peternakan Berkelanjutan III Fakultas Peternakan Universitas Padjadjaran, Jatinangor, 2 November 2011.

[16] Ubaidillah Zuhdi, Nur Arief Rahmatsyah Putranto, Ahmad Danu Prasetyo. "An input - output approach to know the dynamics of total output of livestock sectors: The case of Indonesia". 2nd World Conference On Business, Economics And Management. WCBEM 2013.

[17] https://bps.go.id 